\title{
Application of Mushroom as Food and Medicine
}

\author{
Girma Waktola ${ }^{1}$ and Tasisa Temesgen ${ }^{2 *}$ \\ ${ }^{1}$ Department of Biology, Ambo University, Ethiopia \\ ${ }^{2}$ Department of Natural Resource Management and Environmental Sciences, Haramaya University, Ethiopia
}

Submission: September 10, 2018; Published: September 27, 2018

*Corresponding author: Tasisa Temesgen, School of Natural Resource Management and Environmental Sciences, Haramaya University, Ethiopia, E-mail: tasisatemesgen@gmail.com

\begin{abstract}
A critical review of recent studies on Application of Mushroom as Food and Medicine was conducted from the nutritional contents point of view and as medicinal value. In the review paper, different type's applications of mushrooms as food and medicinal values are expressed shortly. Some mushrooms and other fruiting bodies of filamentous fungi are edible and provide a good source of protein, whereas others have narcotic effects and used as medicine. Mushrooms have rich nutritional value with high content of proteins, vitamins, minerals, fibers, trace elements and low/no calories and cholesterol. They provide the people with an additional vegetable of high quality, and enrich the diet, which can be of direct benefit to the human health and fitness. The extractable bioactive compounds from medicinal mushrooms would enhance human's immune systems and improve their quality of life.
\end{abstract}

Keywords: Antimicrobial; Mushrooms; Food; Nutritional composition and medicine

\section{Introduction}

The word mushroom is used through world to express the different species of fungus belongs to the order of Basidomyecets or Ascomycetes. Basidomyecets or Ascomycetes can be found everywhere in soils rich in organic matter and humus, moist wood, animals waste after heavy rain or a sudden change of temperature and soon after a few hours or day's they disappear, leaving no sign but, mycelium [1]. As estimated by different researchers, there are over 70,000 fungi species on the world. About 2000 species (31 genera) are primarily edible mushrooms. However, about $10 \%$ of some 30 species are poisonous mushrooms and relatively small, numbers are considered as lethal [2].

Mushroom consumption is widely practiced among many ethnic groups of south and southwest Ethiopia. Rural people than urban people eat mushrooms however, older consumer's value mushrooms more than the young do. The tangible information on traditional use of wild mushrooms in Ethiopia is obtained from rural senior citizens. Mushroom is known by few local names for the many species of mushrooms found in the region. In Amharic, the terms Enguday and Yejib tila are used for mushrooms. Yejib tila, which is named after "shadow of the hyena", is a negative term. This seems to be based on the belief that mushrooms appear in places where the animals shadow appeared indicating that growth of mushrooms is somewhat mysterious [3].

Mushrooms are used as therapeutic foods, as they prevent diseases such as hypertension, hypercholesterolemia, atherosclerosis and cancer mainly due to their chemical composition [4]. Mushrooms are the fruiting bodies of certain types of fungi play key roles in forest ecosystems that they have unique abilities to break down wood, leaves, and other organic matter and recycle nutrients back into the system. Pleurotus species are popular and widely cultivated throughout the world mostly in Asia and Europe owing to their simple and low cost production technology and higher biological efficiency [5].

Fekadu [5] describes that, the higher contents of mushrooms is water $(90 \%)$, protein $(2-40 \%)$, fat $(2-8 \%)$, carbohydrates (1$55 \%$ ), fiber (3-32\%), and ash (8-10). High fiber content, proteins, microelements, and lower caloric content are almost ideal for a nutrition program aimed to prevent hypercholesterolemia and cardiovascular diseases. Reduction of total blood cholesterol and lipoprotein cholesterol and antioxidant activities, in the regulation of blood lipid levels and reduction of blood glucose levels [6].

Mushrooms are medicinal foods that are rich in nutrition that recognized by medical professions through the world. Mushrooms have eight important amino acids, polyunsaturated fatty acids and small amounts of saturated fatty acids and have higher nutritional values than fish or beef [5].

\section{Application of mushroom as food and medicine}

\section{Application of mushroom as food}

Mushrooms have a unique texture have good aroma, taste and flavor that differs mushroom from other food crops [7]. 
Edible species of mushrooms found abundantly in indigenous forests are; Macrolepiota, Auricularia, Armillaria, Pholiota, and Coprinus. Several species of Macrolepiota and Agaricus are well known in highland grazing areas. Mushrooms found in exotic plantations such as pinus and cupressus remain unknown to the local people and are not collected for use. The most common poisonous mushroom is Chlorophyllum molybidites, a mushroom similar to other edible members of the Agaricacea and is difficult for local people to differentiate from edible one [3].

Mushrooms are highly nutritive, low-calorie food with good quality proteins, vitamins and minerals. Mushrooms are an important natural source of foods and medicines. By virtue of having high fiber, low fat and low starch, edible mushrooms have been considered to be ideal food for obese persons and for diabetics to prevent hyperglycaemia. They are also known to possess promising anti oxidative, cardiovascular, hypercholesterolemia, antimicrobial, hepato-protective and anticancer effects [8].

As report of Barros et al. [9], more than 3000 mushrooms are mainly edible species but, only 100 species are cultivated commercially, and only ten species are used at industrial scale and their global and economic value is now increasing slowly due to increase in their value as a food as well as their medicinal and nutritional values.

\section{Nutritional composition of mushroom}

\section{Carbohydrate constituent of mushroom:}

The carbohydrate content of mushrooms represents the bulk of fruiting bodies accounting for 50 to $65 \%$ on dry weight basis. Free sugars amount to about $11 \%$. Florezak et al. [10] reported that Coprinus atramentarius contain $24 \%$ of carbohydrate on dry weight basis. The mannitol, also called as mushroom sugar constitutes about $80 \%$ of the total free sugars, hence it is dominant [11]. Singh NB and Singh P [12] reported that, a fresh mushroom contains $0.9 \%$ mannitol, $0.28 \%$ reducing sugar, $0.59 \%$ glycogen and $0.91 \%$ hemicellose. Carbohydrates of Agaricus bisporus are Raffinose, sucrose, glucose, fructose and xylose are dominant in it.

\section{Mushroom as a source of protein}

Protein is an important constituent of dry matter of mushrooms. Protein content of mushrooms depends on the composition of the substratum, size of pileus, harvest time and species of mushrooms [13]. Protein content of the mushrooms has also been reported to vary from flush to flush. Protein in A. bisporus mycelium ranged from 32 to $42 \%$ on the dry weight basis. Mushrooms in general have higher protein content than most other vegetables and most of the wild plants 14.71 to $17.37 \%$ and 15.20 to $18.87 \%$ protein in the fruiting bodies of Lactarious deliciosus and Lactarious sanguiffus respectively. Mushrooms contain all the essential amino acids required by an adult [14].

\section{Fats}

Fat constituent in mushroom is not high when compared with carbohydrates and proteins. The fats present in mushroom fruiting bodies are mostly unsaturated fatty acids. Fat content of mushroom is different in different species that $2.04 \%$ in Suillus granulatus but $3.66 \%$ in Suillus luteus and $2.32 \%$ in A. campestris. Mushrooms are rich in linolenic acid, which is an essential fatty acid. Mushrooms are considered good source of fats and minerals Fat fraction in mushrooms is mainly composed of unsaturated fatty acids $[15,16]$.

\section{Mushroom as source of Vitamins}

Mushrooms are one of the best sources of vitamins especially; wild mushrooms contain much higher amounts of vitamin D2 than dark cultivated Agaricus bisporus. Mushrooms also contain vitamin $\mathrm{B}$-complex and vitamin $\mathrm{C}$ in small amounts, but they are poor in vitamins A, D, and E [17].

\section{Mineral constituents}

Mushrooms are characterized by containing high-level mineral elements that are essential for human health. Major mineral constituents in mushrooms are $\mathrm{K}, \mathrm{P}, \mathrm{Na}, \mathrm{Ca}, \mathrm{Mg}$ and elements like $\mathrm{Cu}, \mathrm{Zn}, \mathrm{Fe}, \mathrm{Mo}$, $\mathrm{Cd}$ form minor. Mushrooms have ability to accumulate heavy metals like $\mathrm{Cd}, \mathrm{Pb}, \mathrm{Ar}, \mathrm{Cu}, \mathrm{Ni}, \mathrm{Ag}$, $\mathrm{Cr}$ and Hg [18]. The mineral contents of mushroom are based on species, age and the diameter of the fruiting body of that mushroom. It also depends upon the type of the substratum that is supplied for mushroom cultivation. The mineral content of wild edible mushrooms is higher than cultivated ones [19].

\section{Application of Mushroom as medicine}

Mushrooms are not only sources of nutrients but also as therapeutic foods, useful in preventing diseases such as hypertension, diabetes, hypercholesterolemia and cancer. These functional characteristics of mushrooms are mainly due to the presence of dietary fiber and in particular chitin and beta glucans. Some mushrooms species have antitumor, antiviral, and antithrombotic and immunomodulating properties and some mushrooms may have potential to lower elevated blood sugar levels [20]. According to the report of [21], Pleurotus species have high medicinal value. Compounds extracted from these mushrooms exhibit activity against various chronic diseases including hypertension, hypercholesterolemia and they are able to possess essential antioxidant, anti-inflammatory and antitumor activities [22].

Agaricus blazei is used general medicine against different diseases, like cancer, chronic hepatitis, diabetes, arteriosclerosis, and hyperlipidemia. Interest in the use of this mushroom and/or its extracts as dietary supplements has increased significantly, in part because of its antitumor, anticarcinogenic, antiviral, anti-inflammatory, hypoglycemic, hypocholesterolemic, and antihypertensive effects. Mushrooms are also used for chronic catarrh diseases of the breast and hinges, lower the cholesterol level of blood, improves circulation, remedy for night sweating 
in tuberculosis, rheumatism, gout, jaundice, dropsy, intestinal worms and have anti-tumor, anti-viral and anti-cancer agents. [23] reported that mushrooms are very effective for patients of hypertension, renal effects and diabetics, their immunemodualatory and antitumor activities of Polysaccharide-Protein Complex (PSPC) from mycelial cultures and their immunemodualatory and antitumor activities of lectins from edible mushrooms gives them valued in medicinal value. Bracket mushroom (Ganoderma lucidum) has been repeatedly used for disease management of patients with HIV and AIDS and can be justified by the increase in body weight.

\section{Mushroom as Antimicrobial action}

Mushroom known as Osmoporus odoratus produce petroleum ether, chloroform, acetone and water extracts that are useful for their antibacterial activity against Staphylococcus aureus, Streptococcus pyogenes, Bacillus subtilis, Escherichia coli and Pseudomonas aeruginosa. The water extract Osmoporus odoratus act as antibacterial activity against the organisms and it is comparable with that of ampicillin rather than chloramphenicol [24].

The antimicrobial activity of many solvent extracts like methanol, ethanol, acetone and aqueous extract of G. lucidum mushroom is applied [25] against six bacterial species E. coli, S. aureus, K. pneumoniae, B. subtilis, S. typhi and P. aeruginosa. Methanolic extracts of six wild mushrooms (L. perlatum, C. cibarius, C. vermiculris, R. formosa, M. oreades, P. pulmonarius) of Western Ghats of Karnataka, India showed significant antimicrobial activity against B. subtilis, S. aureus, E. coli, P. aeruginosa and Candida albicans [26]. The antibacterial and antifungal activity of methanol and aqueous extract of fruit bodies from Phellinus is applied by [27] against five bacterial pathogens such as E. coli, P. aeruginosa, S. typhi, S. aureus and Streptococcus mutans and five fungal strains Penicillium spp, Aspergillus fumigatous, Aspergillus niger, Aspergillus flavus and Mucor indicus [28].

\section{Mushroom as antitumor}

Four mushrooms, Lentinus (Lentinula) edodes, Schizophyllum commune, Grifola frondosa, and Sclerotinia sclerotiorum, particularly their respective $\beta$-glucans, lentinan, schizophyllan (also called SPG, sonifilan, or sizofiran), grifolan, and SSG are known for antitumoral activity. Most of the $\beta$-(1-6)branched $\beta$-(1-3)-linked glucans, are able to act as antitumor activity [29]. Pleurotus rimosus produces ethyl acetate, methanol and aqueus that inhibit the Dalton's Lymphoma Ascites (DLA) cell line induced solid tumor and EAC cell line induced ascites tumor in mice whereas the antitumor effect is high in ethyl acetate extract than the other extracts. Antitumor activity of G. lucidum is again used by [30] through the EAC cell line induced solid tumor model in mice, extracts of methanol and aqueous give significant antitumor properties by inhibiting the tumor development. Polysaccharides extracted from myceliumand fruiting bodies of L. tuberregium effectively inhibited solid tumour proliferation in mice [31].

\section{Anti-inflammatory}

Extracted ethanol from cultured mycelium of M. esculents is well known for its anti-inflammatory activity and is important but based on dose to inhibit both acute and chronic inflammation in mice model that is comparable to the standard Diclofenac. The acute and chronic anti-inflammatory activities of ethyl acetate and methanolic extracts from G. lucidum are expressed [30] through carrageen an induced acute and formalin induced chronic inflammatory models in mice. Chloroform that can extract from G. lucidum is significant anti-inflammatory activity [32].

\section{Mushroom as antioxidant}

Oxidation is essential in many living organisms for the production of energy to fuel biological processes. However, uncontrolled production of oxygen-derived free radicals results in the onset of many diseases, such as cancer, rheumatoid arthritis and atherosclerosis, as well as in degenerative processes associated with aging [33]. Ethyl acetate, methanol and aqueous extract of G. lucidum are highly inhibit $\mathrm{O} 2 \cdot$ and $\cdot \mathrm{OH}$ radicals, but aqueous extract cannot inhibit ferrous ion induced lipid peroxidation whereas ethanol extracts of the mycelium of G. lucidum is high as antiperoxidative activity [34].

\section{Conclusion}

Mushrooms have a long association with humankind and provide profound biological and economic impact. From ancient times, man has consumed wild mushrooms with delicacy probably, for their taste and pleasing flavor. Edible mushrooms provide high quality of protein that can be produced with greater biological efficiency than animal protein, rich in fiber, minerals and different types of vitamins especially, vitamin B-Complex and Vitamin C and have low fat content, with high proportion of polyunsaturated fatty acids relative to total content of fatty acids. Fresh mushrooms contain relatively large amount of carbohydrate (4-5\%) and fiber but, in mushrooms, starch is absent. Mushrooms also contain significant amount of phosphorous, sodium and potassium with lesser amount of calcium and iron. Mushrooms have many potential medicinal uses. Specially, ostreatus has naturally produces isomers of lovastatin, which are well-known blood cholesterol reducing compounds. Several proteins in the ostreatus mushroom have antiviral and even anti-HIV properties.

\section{References}

1. Zeid DC, Savoie JM, Pardo-Gime A (2011) Soybean the main nitrogen source in cultivation substrates of Edible and medicinal mushrooms. Soybean and nutrition.

2. Teferi Yenealem, Diriba Muleta, Delelegn Woyessa (2013) Mushroom consumption habits of Wacha Kebele residents, southwestern Ethiopia; Global Research Journal of Agricultural and Biological Sciences 4(1): 6-16. 


\section{Advances in Biotechnology \& Microbiology}

3. Dawit Abate (2014) Wild Mushrooms and Mushroom Cultivation Efforts in Ethiopia College of Natural Science, Addis Ababa University, Ethiopia.

4. Ashagrie Z Woldegiorgis, Dawit Abate, Gulelat D Haki, Gregory R Ziegler (2015) Proximate and Amino Acid Composition of Wild and Cultivated Edible Mushrooms Collected from Ethiopia, Journal of Food and Nutrition Sciences 3(2): 48-55

5. Fekadu Alemu (2015) Cultivation of Shiitake Mushroom (Lentinus edodes) on Coffee Husk at Dilla University, Ethiopia, Journal of Food and Nutrition Sciences 3(2): 63-70.

6. Daba AS, Kabeil SS, Botros WA, El-Saadani MA (2008) Production of mushroom (Pleurotus streatus) in Egypt as source of nutritional and Medicinal food, World Journal of Agricultural Society 4(5): 630-634.

7. Fekadu Alemu (2014) Cultivation of lentinus edodes on teff straw (agricultural residue) at Dilla University, Ethiopia, Applied Microbiology 1(3): 49-59.

8. Selima Khatun, Aminul Islam, Ugur Cakilcioglu, Narayan C Chatterjee (2012) Mushroom as a Potential Source of Nutraceuticals, American Journal of Experimental Agriculture 2(1): 47-73.

9. Barros L, Cruz T, Baptista P, Estevinho LM, Ferreira IC (2008) Wild and commercial mushrooms as source of nutrients and nutraceuticals. Food Chem. Toxicol 46(8): 2742-2747.

10. Florezak J, Karmnska A, Wedzisz A (2004) Comparision of the chemical contents of the selected wild growing mushrooms, Bromatol. Chem. Toksykol 37: 365-371.

11. Wannet WJB, Hermans JHM, Vander Drift C, Op den Camp HJM (2000) HPCL detection of soluble carbohydrates involved in mannitol and trehalose metabolism in the edible mushroom, Agaricus bisporus, Journal of Agricultural. Food Chemistry 48(2): 287-291.

12. Singh NB, Singh P (2002) Biochemical Composition of Agaricus bisporus. J. Indian Bot. Soc 81: 235-237.

13. Bilal A, Wani R Bodha H, Wani AH (2010) Nutritional and medicinal importance of mushrooms, Journal of Medicinal Plants Research. University of Kashmir, Hazratbal, Srinagar, India 4(24): 2598-2604.

14. Anon Y (2007) Zeri regional project for Africa. Annual Report 2005

15. Yilmaz NM, Solamaz, El mastas M (2006) Fatty acid composition in some wild edible mushrooms growing in the Middle Black region of Turkey, Food Chem 99(1): 168-174.

16. Pedneault KP, Gosselia A, Tweddell RJ (2006) Fatty acid composition of lipids from mushrooms belonging to the family Boletaceae, Mycology. Res 110(10): 1179-1183.

17. Heleno SA, Barros L, Martins A, Queiroz MJ, Santos Buelga C, et al (2012) Phenolic, Polysaccharidic and Lipidic Fractions of Mushrooms from Northeastern Portugal, Chemical Compounds with Antioxidant Properties. Journal of Agricultural and Food Chemistry 60(18): 46344640.

18. Malinowska E, Szefer P, Faradays J (2004) Metals bioaccumulation by bay Bolete, Xerocomos badius from selected sites, Food Chemistry 84(3): 405-416.

19. Rudawska M, Leski T (2005) Macro and micro elemental contents in fruiting bodies of wild mushrooms from the Netecka forest in west central Poland, Food Chemistry 92(3): 499-502.

20. Md Asaduzzaman Khan, Mousumi Tania (2012) Nutritional and Medicinal Importance of Pleurotus Mushrooms, Food Reviews International 28(3): 313-329.

21. Wasser SP (2002) Medicinal mushrooms as source of antitumor and immunomodulating polysaccharides. Applied Microbiol and Biotechnology 60(3): 258-274.

22. Jose N, Ajith TA, Janardhanan KK (2002) Antioxidant, anti-inflammatory and antitumor activities of culinary medicinal mushroom Pleurotus pulmonarius (Fr.) Quel. (Agaricomycetideae). International journal of medicinal mushroom, 4(4): 329-335.

23. Sasidharan S, Aravindran S, Lachimanan YL, Ratnasamy V, Saravanan D, et al. (2010) In vitro antioxidant activity and hepatoprotective effects of Lentinula edodes against paracetamol-induced hepatotoxicity, Molecules 15(6): 4478- 4489.

24. Sivakumar R, Vetrichelvan T, Rajendran NN, Indira Devi $M$, Sundaramoorthi K, et al. (2006) Antibacterial activity of mushroom Osmoporus odoratus, Indian J. Pharma, Sci 68(4): 523-524.

25. Quereshi S, Pandey AK, Sandhu SS (2010) Evaluation of antibacterial activity of different Ganoderma lucidum extracts. People's J. Scientific Res 3(1): 9-13.

26. Ramesh C, Pattar MG (2010) Antimicrobial properties, antioxidant activity and bioactive compounds from six wild edible mushrooms of Western Ghats of Karnataka, India. Pharmacognosy Res 2(2): 107-112.

27. Balakumar R, Sivaprakasam E, Kavitha D, Sridhar D, Kumar JS (2011) Antibacterial and antifungal activity of fruit bodies of Phellinus mushroom extract. International journal of bioscience 1(3): 72-77.

28. Hrudayanath T, Sameer KS (2014) Diversity, nutritional composition and medicinal potential of Indian mushrooms, African journal of Biotechnology, Biju Patnaik University of Technology, Bhubaneswar, Odisha, India.

29. Fekadu Alemu (2014) Cultivation of pleurotus ostreatus on grevillea robusta leaves at Dilla University, Ethiopia, Journal of yeast and Fungal Research 5(6): 74-83.

30. Sheena N, Lakshmi B, Janardhanan KK (2005) Therapeutic potential of Ganoderma lucidum (Fr.) P. Karst. Nat. Prod. Rad 4(5): 382-386.

31. Manjunathan J, Kaviyarasan V (2010) Nutrient composition in wild and cultivated edible mushroom, Lentinus tuberregium (Fr.) Tamil Nadu, India. International Food Resource. Journal 18(2): 59-61.

32. Joseph S, Sabulal B, George V, Smina TP, Janardhanan KK (2009) Antioxidative and anti-inflammatory activities of the chloroform extract of Ganoderma lucidum found in South India. Sci Pharm 77(1): 111-121.

33. Halliwell B (2003) Antioxidants in human health and disease, Annual Review of Nutrition 16:33-50.

34. Lakshmi B, Ajith TA, Sheena M, Nidhi G, Janardhanan KK (2003) Antiperoxidative, anti-inflammatory and ant mutagenic activities of ethanol extract of the mycelium of Ganoderma lucidum occurring in South India; Teratogen Carcinogen Mutagen. 1: 85-97. 
This work is licensed under Creative Commons Attribution 4.0 Licens DOI: 10.19080/AIBM.2018.11.555817
Your next submission with Juniper Publishers will reach you the below assets

- Quality Editorial service

- Swift Peer Review

- Reprints availability

- E-prints Service

- Manuscript Podcast for convenient understanding

- Global attainment for your research

- Manuscript accessibility in different formats

( Pdf, E-pub, Full Text, Audio)

- Unceasing customer service

Track the below URL for one-step submission https://juniperpublishers.com/online-submission.php 